\title{
MICROSTRUCTURAL DEVELOPMENTS AND MECHANICAL PROPERTIES OF FRICTION STIR WELDING OF AZ91D MAGNESIUM ALLOY PLATES
}

\author{
K. N. B.Kumar ${ }^{*}$, C. Vanitha \\ Department of Metallurgical and Materials Engineering, \\ National institute of Technology, Warangal, India.
}

Received 01.09.2016

Accepted 21.06.2017

\begin{abstract}
Friction stir welding (FSW) is an efficient technique which can be used particularly for magnesium and aluminum alloys that are difficult to fusion weld. In this work AZ91D Mg alloy plates 3mm thick were friction stir welded at different process variables such as rotational speed and welding speed. The range of rotational speeds varied from 1025 to $1525 \mathrm{rpm}$, and the welding speed varied from 25 to $75 \mathrm{~mm} / \mathrm{min}$. Good quality welds were obtained under $1025 \mathrm{rpm}$ of rotational speed with the welding speeds range from 25 to $75 \mathrm{~mm} / \mathrm{min}$. The microstructure of the AZ91D alloy consists of primary $\alpha$-phase, eutectic $\alpha$-phase and eutectic $\beta\left(\mathrm{Mg}_{17} \mathrm{Al}_{12}\right)$ phase in the received condition (gravity die cast). The original dendrite grain structure completely disappeared and was transformed to fine equiaxed grains in stir zone (SZ). It was observed that there was a slight increase in hardness in SZ, because of fine recrystallized grain structure. The transverse tensile test results of weld specimens indicated constant strength irrespective of traveling speed. Fractrographic analysis of the friction stir welded specimens showed the brittle failure.
\end{abstract}

Key words: Magnesium based alloys; AZ91D Mg Alloy; Friction stir welding; Dynamic recrystallization.

\section{Introduction}

Magnesium based alloys are emerging as an essential engineering materials, especially in the automobile and aerospace sectors, because of their high damping capacity and recyclability, high strength-to-weight ratio, low density [1]. These alloys, having a density of about two-thirds of $\mathrm{Al}$ alloys, are the promising engineering materials to boost fuel economy especially for the automotive industry [2,3]. At present magnesium based alloys are mainly used to develop cast based products. Their utility in

* Corresponding author: K. N. B Kumar: knbkumar@nitw.ac.in 
wrought form is low and there are expectations to increase in the upcoming years. However, the main drawback of $\mathrm{Mg}$ based alloy as a structural material is its high chemical activity leading in many cases to a low welding characteristics and corrosion resistance [4]. Consequently, joining of $\mathrm{Mg}$ alloys by conventional fusion welding process leads to a variety of problems, including porosity, liquation and solidification cracking, loss of alloying elements, oxide inclusion etc. [5].

Due to the above mentioned reasons, fusion welding of magnesium based alloys is unreliable. Friction stir welding (FSW) is the suitable solid state process to join $\mathrm{Mg}$ alloys, which eliminates welding defects associated with conventional fusion welding process. Joints produced using FSW process show better mechanical properties such as the tensile strength, elongation, and hardness in comparison with conventional fusion welding methods. FSW is solid state joining technique which was invented at the welding institute of United Kingdom in 1991 and was initially applied to join Al alloys [6]. Due to these advantages, FSW has become an excellent candidate for joining of different materials such as nickel based alloys, steels and titanium alloys [7]. Unlike these high strength materials, magnesium alloys have low melting point and low strength, which are amicable for FSW like aluminum alloys [1].

Different commercial grade magnesium alloys such as ZM21, AZ31 [8-10], Mg$\mathrm{Zn}-\mathrm{Y}-\mathrm{Zr}$ [11], are joined using FSW process, giving their best results over conventional fusion welding process.

Kazuhiro Nakata [12] has investigated various FS welded magnesium alloys. He reported that mechanical properties were improved over conventional fusion welding technique. Won-Bae Lee et al. [13] investigated joint characteristics of friction stir welded AZ91D magnesium alloy joints and reported that $\beta$ intermetallic phase was dissolved in the stir zone due to frictional heat input. Cao et al. [14] have investigated effect of probe length and rotational speed on friction stir lap joint of AZ31B-H24 magnesium having $2 \mathrm{~mm}$ thickness and reported that by increasing tool rotational speed tensile shear load increases initially but decreases by further increase of rotational speed. Xunhong et al. [15] have investigated friction stir butt-welded AZ31 magnesium alloy plates $4 \mathrm{~mm}$ thick and reported that tensile strength of the joint attained $93 \%$ that of the base metal and the fractured location was heat effected zone. Afrin et al. [16] investigated friction stir welded AZ31B magnesium alloy and reported that grains in the stir zone and thermo-mechanically effected zone experienced recrystallization and growth and the shape of the grain became equiaxed, having smaller values of both fractal dimension and aspect ratio. Cavaliere et al. [17] have investigated the effect of friction stir processing (FSP) on superplastic nature of AZ91 magnesium alloy and reported that it exhibited good ductile and strength properties due to fine structure by processing route at room temperature when compared to base metal. Darras et al. [18] have investigated the effect of FSP on commercial AZ31 magnesium alloy and reported that microstructural homogenization and refinement of grain are achieved in a single FSP pass over the surface of base metal. Rong-chang et al. [19] investigated effect of FSW on AM50 magnesium alloy and reported that microstructure was recrystallized having smaller size of equiaxed grains containing $\alpha-\mathrm{Mg}$ matrix and $\beta$ phase. Rose et al. [20] investigated the effect of axial force on during FSW of AZ61A Mg alloy and reported that it has significant influence on the formation of defects, grain size, hardness of stir zone and tensile strength. Cavaliere et al. [21] reported that fatigue life of the friction stir processed AZ91 magnesium alloy was increased during processing 
compared to the base material in as-cast condition. Chai et al. [22] investigated submerged friction stir processed AZ91 magnesium alloy and reported that after processing coarse $\beta \mathrm{Mg}_{17} \mathrm{Al}_{12}$ phase network changed into particles pinned on the grain boundaries. Park et al. [23] found texture and flow pattern in friction stir welded AZ61 $\mathrm{Mg}$ alloy and reported that onion ring structure in stir zone and nugget shape are associated with the presence of (0002) basal plane having elliptical trace surface. Park et al. [24] have investigated FSW of thixomolded Mg alloy AZ91D and reported that microstructure containing primary solid particles is transformed to fine equiaxed grains of $\alpha-\mathrm{Mg}$ phase during welding. Hardness of stir zone was increased with decreasing grain size in relation to Hall-Petch equation. An extensive literature survey revealed that only limited amount of work has been carried out on the FSW of magnesium based alloys when compared to Al alloys. The present paper reports our primary results on FSW of gravity die cast AZ91 Mg alloy, widely considered for use in automobile and aerospace industries.

\section{Experimental Procedures}

Base Material

The base material AZ91D Mg alloy used in the present study was supplied by Exclusive Magnesium Pvt. Ltd, Hyderabad in the form of as-cast blocks; $3 \mathrm{~mm}$ thick plates were prepared from the blocks of dimension $130 \mathrm{X} 45 \mathrm{~mm}$ using wire cut electrical discharge machine (EDM) and chemical composition is given in Table 1.

Table 1. Chemical Composition of AZ91D Mg alloy

\begin{tabular}{lccccccc}
\hline Element & $\mathrm{Al}$ & $\mathrm{Zn}$ & $\mathrm{Si}$ & $\mathrm{Cu}$ & $\mathrm{Ni}$ & $\mathrm{Mn}$ & $\mathrm{Mg}$ \\
\hline Wt. \% & 8.84 & 0.59 & 0.22 & 0.05 & 0.008 & 0.21 & Balance \\
\hline
\end{tabular}

\section{Friction stir welding of AZ91D Mg alloy plates}

Prior to welding, surface oxides of plates are removed by stainless steel brush, and then the $3 \mathrm{~mm}$ thick plates were cleaned with acetone in order to remove any surface pollutant. At different travel speeds varied from 1025 to $1525 \mathrm{rpm}$ and welding speeds varied from 25 to $75 \mathrm{~mm} / \mathrm{min}$ the friction stir welding operations were performed. Butt joint welds, $3 \mathrm{~mm}$ thick, were produced using a commercially available vertical milling machine at IIT, Roorkee. The plunge depth varied from $0.2 \mathrm{~mm}$ to $0.1 \mathrm{~mm}$ excess of pin length for travel speeds 1025 to $1525 \mathrm{rpm}$. The process parameters used in this study are listed in Table 2. 
Table 2. Welding parameters used for the present study

\begin{tabular}{|c|c|c|c|c|c|c|}
\hline Nomenclature & \multicolumn{6}{|c|}{ Corresponding processing parameters } \\
\hline Tool details & \multicolumn{6}{|c|}{$\begin{array}{l}\text { H13 tool steel Tapered cylindrical pin (left hand metric threads, } \\
0.5 \mathrm{~mm} \text { pitch) } \\
\text { Pin diameter: } 7 \mathrm{~mm} \text { (shoulder end) and } 2 \mathrm{~mm} \text { (tip end) } \\
\text { Pin length: } 2.6 \mathrm{~mm} \\
\text { Shoulder diameter: } 18 \mathrm{~mm}\end{array}$} \\
\hline $\begin{array}{l}\text { Tool rotational } \\
\text { speed }(\mathbf{r p m})\end{array}$ & 1025 & 1025 & 1025 & 1525 & 1525 & 1525 \\
\hline $\begin{array}{l}\text { Welding speed } \\
(\mathrm{mm} / \mathrm{min})\end{array}$ & 25 & 50 & 75 & 25 & 50 & 75 \\
\hline Plunge depth & $\begin{array}{l}0.2 \\
\text { mm } \\
\text { excess } \\
\text { of pin } \\
\text { length }\end{array}$ & $\begin{array}{l}0.2 \mathrm{~mm} \\
\text { excess of } \\
\text { pin } \\
\text { length }\end{array}$ & $\begin{array}{l}0.2 \mathrm{~mm} \\
\text { excess of } \\
\text { pin } \\
\text { length }\end{array}$ & $\begin{array}{l}0.1 \mathrm{~mm} \\
\text { excess of } \\
\text { pin } \\
\text { length }\end{array}$ & $\begin{array}{l}0.1 \mathrm{~mm} \\
\text { excess } \\
\text { of pin } \\
\text { length }\end{array}$ & $\begin{array}{l}0.1 \mathrm{~mm} \\
\text { excess of } \\
\text { pin } \\
\text { length }\end{array}$ \\
\hline Dwelling time & \multicolumn{6}{|c|}{10 seconds } \\
\hline
\end{tabular}

\section{Metallography}

In the transverse direction, the cross sectional welded specimens were prepared by standard metallographic polishing procedure. The weld specimens were etched with acetic glycol for 10-15 s prior to examination using optical and scanning electron microscopy. Acetic glycol etchant is composed of $60 \mathrm{ml}$ ethylene glycol, $20 \mathrm{ml}$ acetic acid, $20 \mathrm{ml}$ distilled water and $1 \mathrm{ml}$ nitric acid.

Microstructural and elemental analysis of the weldments and fractured surfaces were analyzed using a VEGA 3 TESCAN scanning electron microscope.

Microstructural observation of the weldments was analyzed using a QUASMO model no: QMM-500 optical microscope.

Tensile testing

Transverse tensile tests were performed to determine the joint strength of the welds. Test specimens were prepared according to the standard ASTM E8 with a wire cut EDM. The tensile tests were conducted at room temperature using Instron Model no. S500 testing machine, at cross head speed of $2 \mathrm{~mm} / \mathrm{min}$.

\section{Microhardness testing}

Microhardness was measured using Shimadzu micro hardness tester. The load of $200 \mathrm{~g}$ was applied for $15 \mathrm{~s}$.

\section{Results and discussion}

Effect of processing parameters on friction stir welding of AZ91D Mg Alloy

The butt welding joints produced with different welding conditions are shown in Fig. 1. 

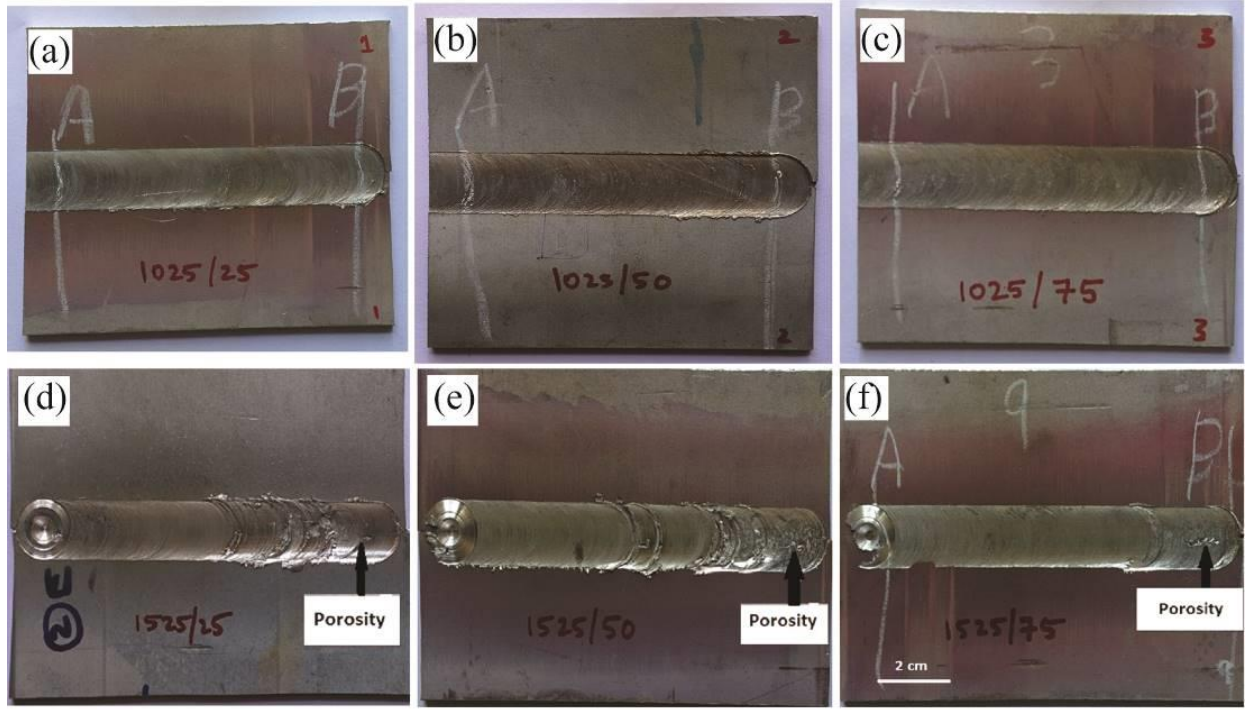

Fig. 1. Surface appearances with various welding conditions: 1025 rpm at (a) $25 \mathrm{~mm} / \mathrm{min}$, (b) $50 \mathrm{~mm} / \mathrm{min}$, (c) $75 \mathrm{~mm} / \mathrm{min}, 1525 \mathrm{rpm}$ at (d) $25 \mathrm{~mm} / \mathrm{min}$, (e) $50 \mathrm{~mm} / \mathrm{min}$, (f) $75 \mathrm{~mm} / \mathrm{min}$.

As shown in Fig. 2 defects were observed for the samples welded at $1525 \mathrm{rpm}$ rotational speed irrespective of the welding speed.
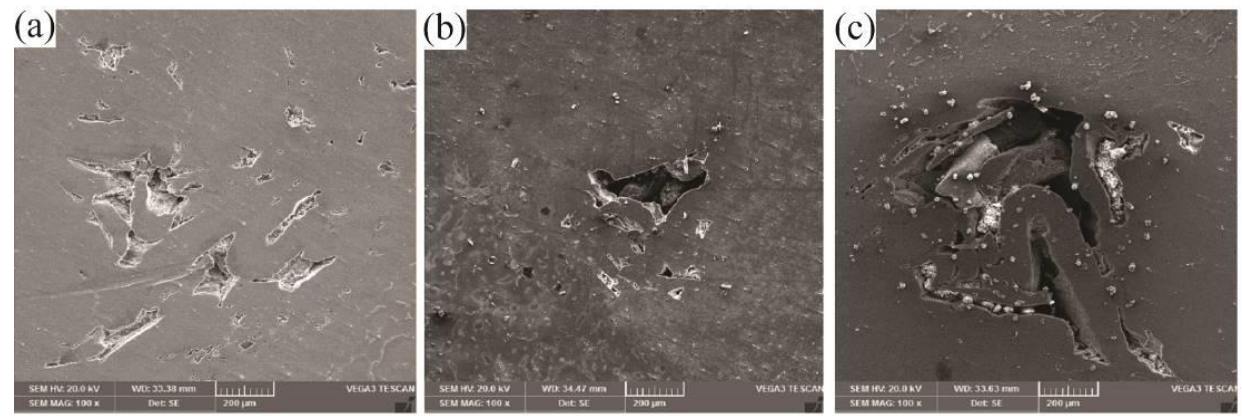

Fig. 2. SEM image in the SZ of the AZ91D Mg alloy friction stir welded (1525 rpm) at conditions: (a) $25 \mathrm{~mm} / \mathrm{min}$, (b) $50 \mathrm{~mm} / \mathrm{min}$, (c) $75 \mathrm{~mm} / \mathrm{min}$.

Porosity was observed on the top surface and the voids were present in the stir zone observed for the tool rotation of $1525 \mathrm{rpm}$, and welding speeds ranging from 25 to $75 \mathrm{~mm} / \mathrm{min}$. Good quality joints (defect free) were produced for the condition of 1025 $\mathrm{rpm}, 25$ to $75 \mathrm{~mm} / \mathrm{min}$, respectively. 

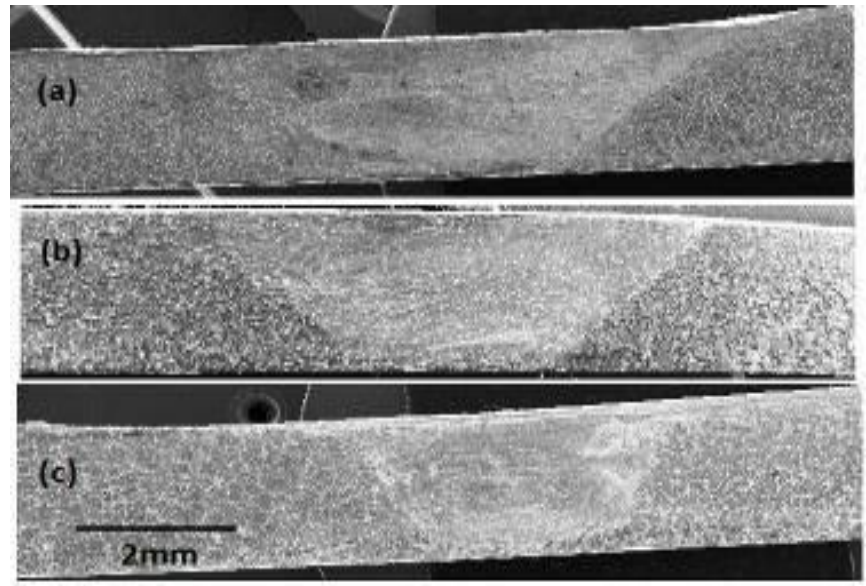

Fig. 3. Macrostructures of cross sectional joints $1025 \mathrm{rpm}$ at (a) $25 \mathrm{~mm} / \mathrm{min}$,

(b) $50 \mathrm{~mm} / \mathrm{min}$, and (c) $75 \mathrm{~mm} / \mathrm{min}$.

Fig. 3 shows the transverse cross sectional macrostructures of the joints welded at different processing parameters. The weld zone is wider at the top surface than at the bottom surface, because the top surface has experienced frictional heat and extreme deformation by contacting taper cylindrical tool shoulder with surface of the joint to be welded. The shape of the stir zone is mostly like pin profile. The shape of nugget zone is influenced by pin profile, materials to be welded, and the rate of their thermal conductivity.

Fig. 2 shows small defects, formed in the advancing side of stir zone named as tunnel voids. These defects are the result of the brittleness of AZ91D Mg alloy and are not caused due to insufficient heat input. Both surface porosity and tunnel voids in stir zone are observed for condition of $1525 \mathrm{rpm}, 25$ to $75 \mathrm{~mm} / \mathrm{min}$. From the weld inspection of stir zone for condition of $1025 \mathrm{rpm}$, fixed rotational speed and varying welding speed 25 to $75 \mathrm{~mm} / \mathrm{min}$ no defects in the weld zone were observed, as shown in Fig. 3.

\section{Microstructure of the weld zones}

The microstructure of the base material showed the mixture of primary $\alpha$ phase and eutectic structure which consists of $\mathrm{Mg}$ solid solution (eutectic $\alpha$ phase) and $\beta$ intermetallic compounds (eutectic $\beta\left(\mathrm{Al}_{12} \mathrm{Mg}_{17}\right)$ ) as shown in Fig. 4 and their respective chemical composition measured through EDS technique is presented in Table3. 


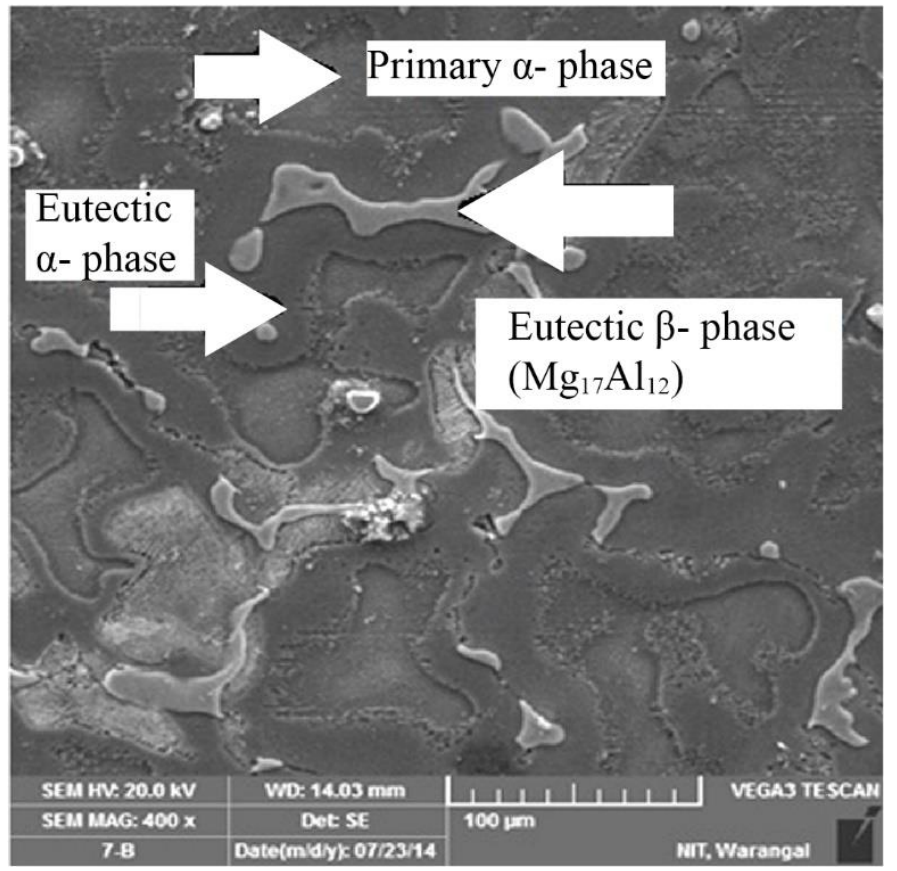

Fig. 4. SEM micrograph of the AZ91D base metal: (1) primary $\alpha$-phase, (2) eutectic $\alpha$-phase, (3) eutectic $\beta$ phase $\left(M_{17} A l_{12}\right)$.

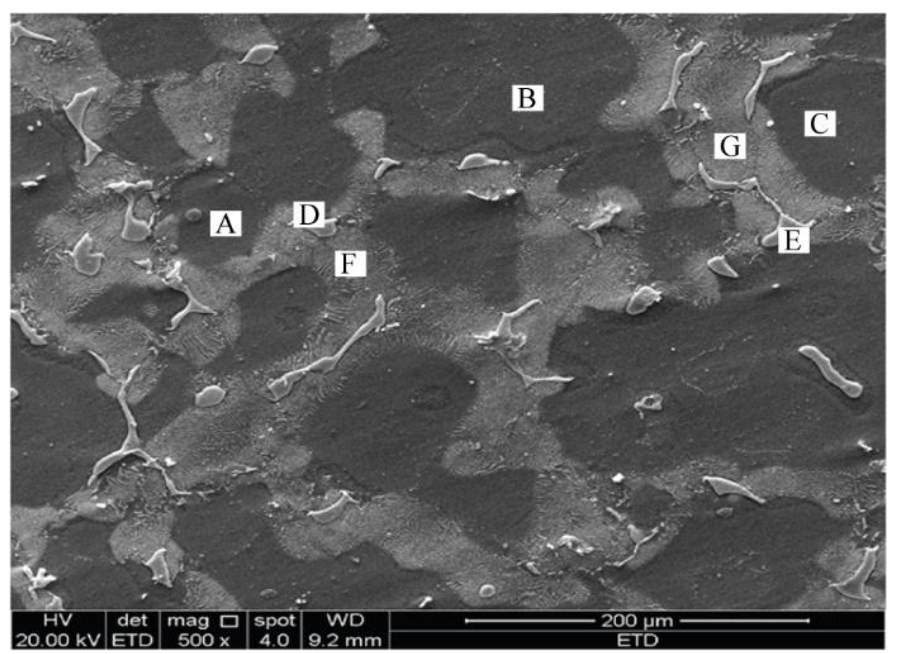

Fig. 5. SEM image of as received sample. EDS analysis at different spots (A to G). 
Table 3. EDS elemental analysis of as received sample

\begin{tabular}{lccccccc}
\hline Elements & Spot A & Spot B & Spot C & Spot D & Spot E & Spot F & Spot G \\
\hline $\mathrm{Mg}$ & 87.62 & 87.86 & 80.36 & 55.68 & 56.17 & 79.86 & 80.23 \\
$\mathrm{Al}$ & 6.53 & 4.67 & 9.16 & 38.67 & 37.39 & 11.55 & 9.59 \\
$\mathrm{Zn}$ & 5.85 & 7.47 & 10.46 & 5.64 & 6.50 & 8.59 & 10.17 \\
\hline
\end{tabular}

From Fig. 5 and Table 3 the EDS spot analysis of the different regions of the base metal confirmed that the amount of $\mathrm{Mg}$ was found to be rich in all phases. However, the amount of aluminum in eutectic $\beta$ was found to be higher as compared to the primary $\alpha$ and eutectic $\alpha$ phase.

Figs. 6-8 show the microstructures of the different zones of the friction stir welded samples at $1025 \mathrm{rpm}$, at different travel speeds. The welds consist of three regions named as heat affected zone (HAZ) (a), thermo-mechanically affected zone (TMAZ) (b), and stir zone (SZ) (c). Each zone exhibits different features of microstructure depending on the thermal and mechanical conditions. In the HAZ, due to thermal effect produced by tool, the volume of $\beta$ intermetallic compound undergoes dissolution and its volume fraction was found to be rather small. TMAZ, where the combined effects of thermal and plastic deformation were active, is composed of partially observable $\beta$ intermetallic compounds and fine recrystallized grains. Intermetallic compound $\beta$ was located around the direction of tool rotation. In the SZ, the original dendrite grain structure of base metal was transformed to fine equiaxed grain structure. Intermetallic compound $\beta$ disappeared due to transformation of $\beta$ phase into $\alpha$ phase by diffusion.
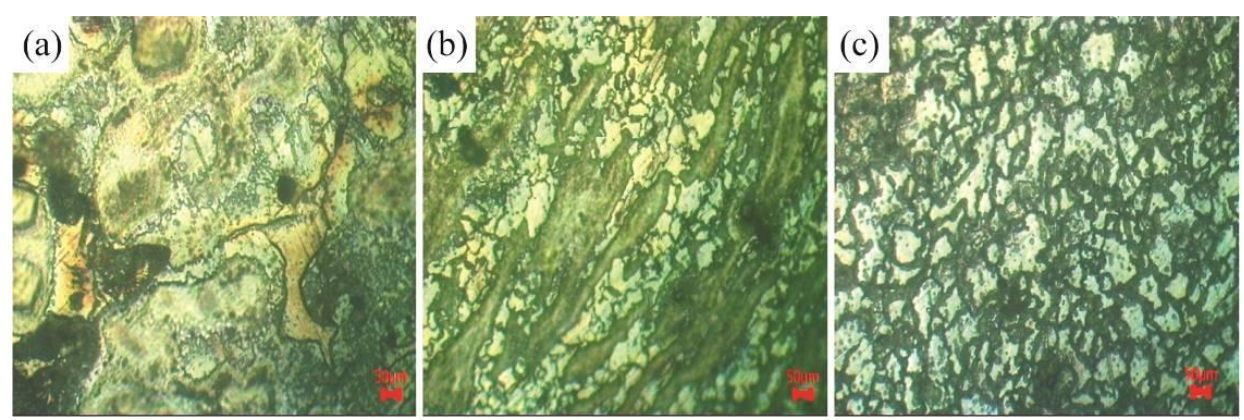

Fig. 6. Optical micrographs for $1025 \mathrm{rpm}, 25 \mathrm{~mm} / \mathrm{min}$ near the welds (a) HAZ, (b) TMAZ, (c) SZ. 

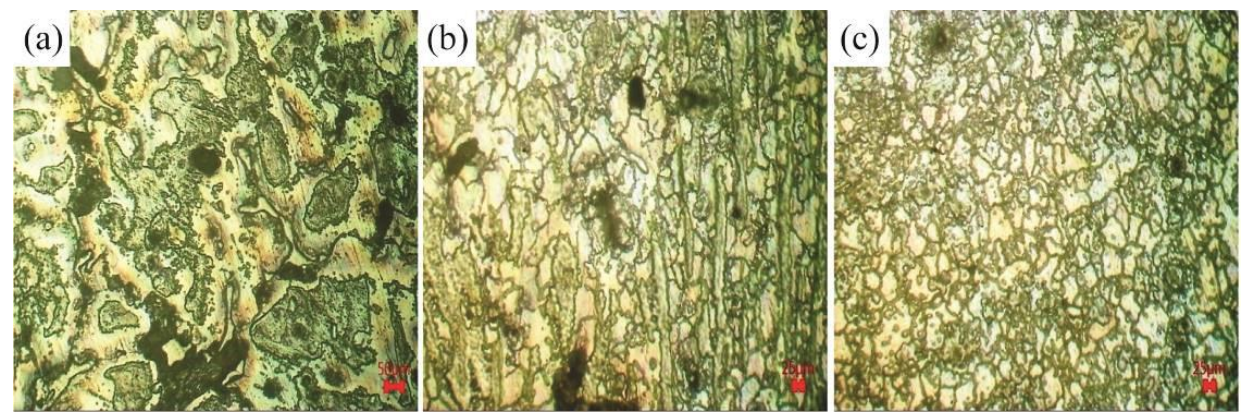

Fig. 7. Optical micrographs for $1025 \mathrm{rpm}, 50 \mathrm{~mm} / \mathrm{min}$ near the welds (a) HAZ, (b) TMAZ, (c) SZ.
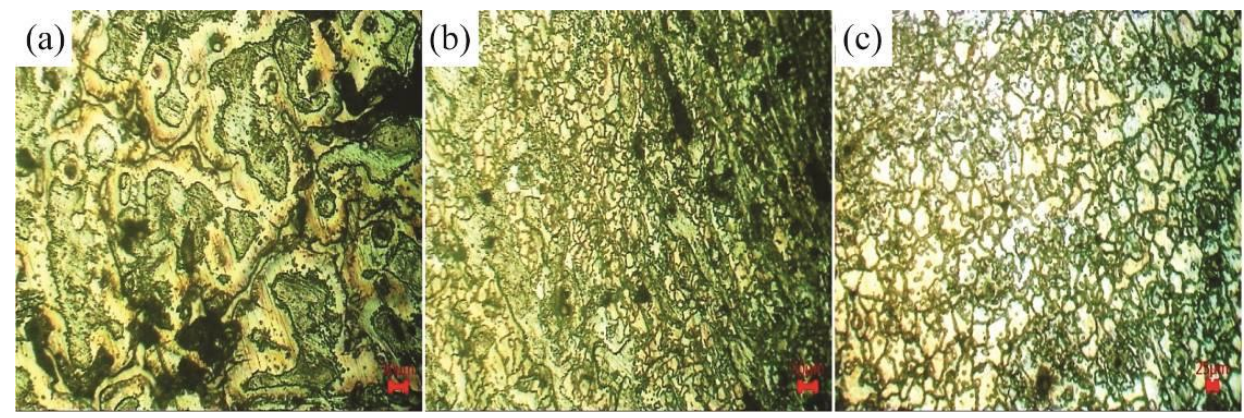

Fig. 8. Optical micrographs for $1025 \mathrm{rpm}, 75 \mathrm{~mm} / \mathrm{min}$ near the welds (a) HAZ,

(b) TMAZ, (c) SZ.

Fig. 6(c), 7(c), and 8(c) show the microstructure of stir zones with various traveling speeds at fixed rotational speed $1025 \mathrm{rpm}$. The original dendrite structure of the base material got completely disappeared in the stir zone. The stir zone undergoes dynamic recrystallization. This is due to heat generated by friction between the material and tool and high strain rates applied to the material surface by the tool pin. Each stir zone shows different grain size with increasing welding speed. At $25 \mathrm{~mm} / \mathrm{min}$ welding speed the grain size was found to be $21 \mu \mathrm{m}$, at $50 \mathrm{~mm} / \mathrm{min}$ grains were becoming smaller, i.e. $13 \mu \mathrm{m}$, whereas at $75 \mathrm{~mm} / \mathrm{min}$ grains of only $7 \mu \mathrm{m}$ were found in the microstructure. This can be expressed by simple equation, heat input per unit length, $\mathrm{Q} / \mathrm{V}$, where $\mathrm{Q}$ is heat generated due to friction between material and tool and $\mathrm{V}$ is the traveling speed. As tool rotational speed increases, Q also increases [10]. As a consequence, with increasing welding speed the heat input decreases. Thus, the grain size is coarser with decreasing welding speed due to enhancement of heat input, which promotes the growth of recrystallization of grains. However, the poor formability of AZ91D Mg alloy and lots of intermetallic compounds (such as $\mathrm{Al}_{12} \mathrm{Mg}_{17}$ ), present in base material, influence the range of weld conditions.

\section{Microhardness measurements}

Fig. 9 shows Vickers microhardness profiles of transverse section of the weldment for different conditions: $1025 \mathrm{rpm}, 25 \mathrm{~mm} / \mathrm{min} ; 1025 \mathrm{rpm}, 50 \mathrm{~mm} / \mathrm{min}$; and $1025 \mathrm{rpm}, 75 \mathrm{~mm} / \mathrm{min}$. The hardness range was wide due to different phases present in 
the base material. The average hardness of the base material was $68 \mathrm{HV}$. The weld center showed the hardness of $100 \mathrm{HV}$. The hardness decreased to $65 \mathrm{HV}$ with increasing the distance from the weld center irrespective of the travel speed. The reason for hardness variation is $\mathrm{Mg}$ solid solution which is softer than $\beta$ intermetallic compound and has larger volume fraction. The hardness of SZ is increased showing uniform distribution due to the fine and recrystallized grain structure. The hardness profile depends upon the range of welding speeds. As travelling speed increases, the hardness of the stir zone increases remarkably due to the grain refinement. However, at higher traveling speed, the hardness profile of the SZ is non-uniformly distributed due to microstructural irregularity.

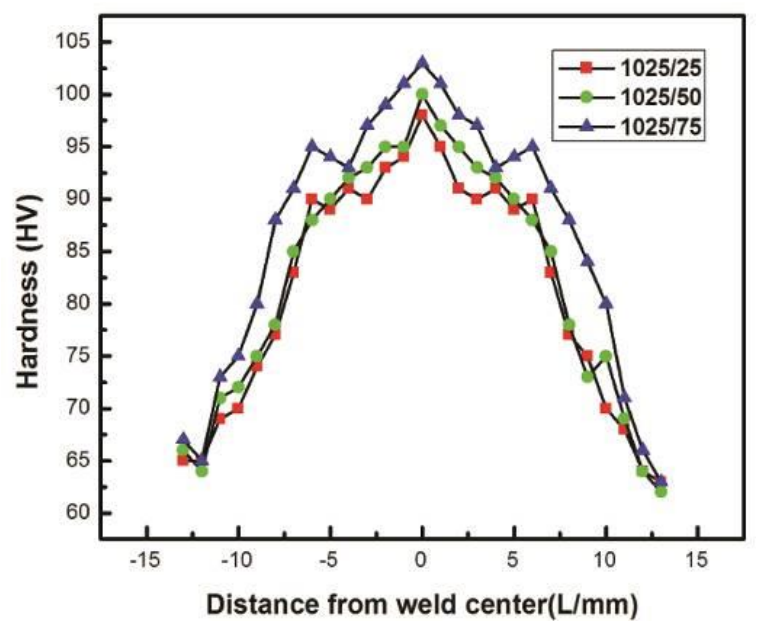

Fig. 9. Hardness distributions of the welds with various welding speeds

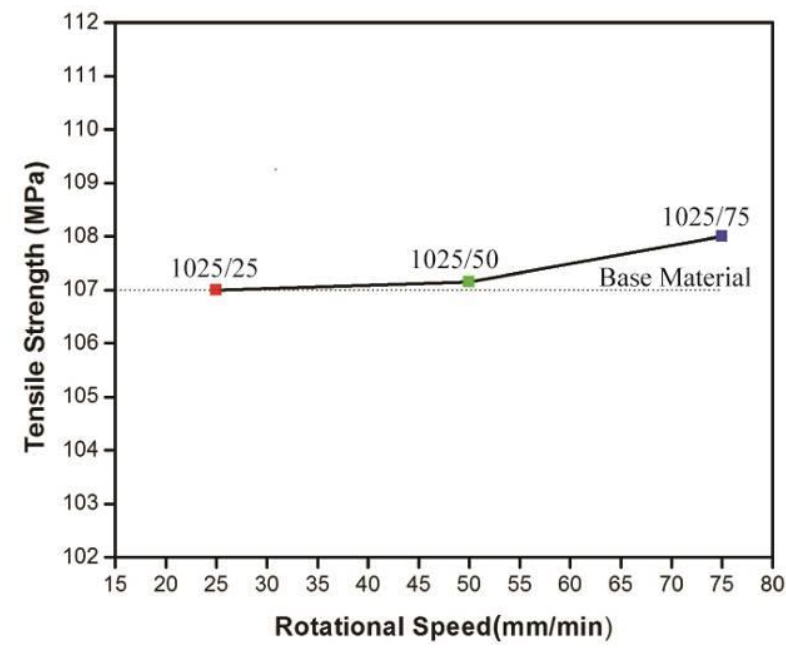

Fig. 10. Ultimate tensile strength variations with various welding speeds 

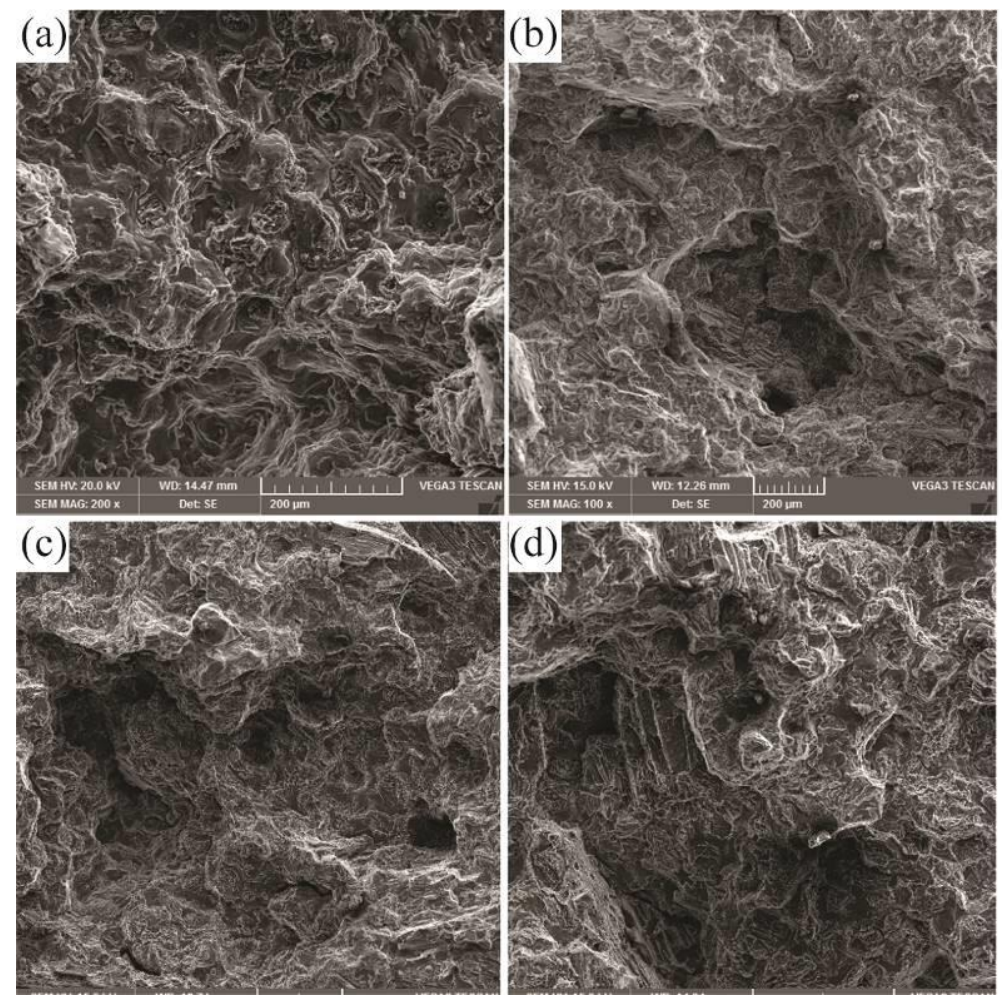

Fig.11. SEM images of fracture surface. (a) Base material, (b) welded plate: $1025 \mathrm{rpm}$, $25 \mathrm{~mm} / \mathrm{min}$; (c) welded plate: $1025 \mathrm{rpm}, 50 \mathrm{~mm} / \mathrm{min}$; (d) welded plate: $1025 \mathrm{rpm}$, $75 \mathrm{~mm} / \mathrm{min}$.

\section{Tensile testing}

Fig. 10 shows the transverse tensile strength with various welding speeds. The base material has tensile strength of $107 \mathrm{MPa}$. The tensile strength results show almost the same values of the base material regardless of travelling speeds. The non-uniformly distributed eutectic $\beta$ phase- $\mathrm{Al}_{12} \mathrm{Mg}_{17}$ and shrinkage defects present in the base material are responsible for preferential crack initiation. Due to this reason weld specimen failed at unaffected base metal. The presence of quasi-cleavage fractured surfaces in Fig. 11 confirms that AZ91D Mg alloy and friction stir welded specimens failed through brittle facture.

\section{Conclusions}

1. Defect- free welds were produced for the welding conditions of $1025 \mathrm{rpm}, 25$ $\mathrm{mm} / \mathrm{min} ; 1025 \mathrm{rpm}, 50 \mathrm{~mm} / \mathrm{min}$ and $1025 \mathrm{rpm}, 75 \mathrm{~mm} / \mathrm{min}$.

2. Welding defects like tunnel voids and surface porosity were observed for the welding conditions of $1525 \mathrm{rpm}, 25 \mathrm{~mm} / \mathrm{min} ; 1525 \mathrm{rpm}, 50 \mathrm{~mm} / \mathrm{min}$ and $1525 \mathrm{rpm}, 75 \mathrm{~mm} / \mathrm{min}$.

3. The original dendritic grain structure of the base material was completely eliminated in the stir zone. It was replaced with fine and equiaxed grains 
while $\beta$ intermetallic phase was dissolved due to frictional heat input produced by the tool.

4. In the stir zone grain refinement occurs due to dynamic recrystallization.

5. The mechanical properties such as tensile strength and hardness were improved due to the grain refinement in the stir zone.

\section{Acknowledgements}

The authors would like to thank MHRD, Government of India, and Director, N.I.T, Warangal for funding support to this research work.

\section{References}

[1] K. L. Harikrishna, J. J. S. Dilip, K. Ramaswamy Choudary, V. V. Subba Rao, S. R. Koteswara Rao, G. D. Janaki Ram, N. Sridhar, G. Madhusudhan Reddy: Trans Indian Inst Met, 63 (2010) 807-811.

[2] S. F. Su, H. K. Lin, J. C. Huang, N. J. Ho: Metall Mater Trans A, 33 (2002) 14611473.

[3] A. Benartzy, A. Munitz, G. Kohn, B. Brining, A. Shtechman, In: Proceedings Magnesium Technology, Seattle, WA, USA: TMS, 2010, p. 295-302.

[4] L. Liu, Welding and joining of magnesium alloys, 1st ed. Woodhead Publishing, 2010.

[5] X. Cao, M. Jahazi, J. P. Immarigeon, W. Wallace: J Mater Process Technol, 171(2006) 188-204.

[6] J. Marzbanrad, M. Akbari, P. Asadi, S. Safaee: Metall Mater Trans B, 45(2014) 1887-1894.

[7] H. K. D. H. Bhadeshia, T. DebRoy: Sci Technol Weld Joining, 14 (2009) 193-196.

[8] G. Padmanaban, V. Balasubramanian: Mater Des 30 (2009) 2647-2656.

[9] U. F. H. R. Suhuddin, S. Mironov, Y. S. Sato, H. Kokawa, C-W. Lee: Acta Mater, 57 (2009) 5406-5418.

[10] N. Afrin, D. L. Chen, X. Cao, M. Jahazi: Mater Sci Eng A, 472 (2008) 179-186.

[11] G. M. Xie, Z. Y. Ma, L. Geng, R. S. Chen: Mater Sci Eng A, 471 (2007) 63-68.

[12] K. Nakata: Weld Int, 23 (2009) 328-332.

[13] Won-Bae Lee, Jong-Woong Kim, Yun-Mo Yeon, Seung-Boo Jung: Mater Trans, 44 (2003) 917-923.

[14] X. Cao, M. Jahazi: Mater Des, 32.1 (2011) 1-11.

[15] W. Xunhong, W. Kuaishe: Mater Sci Eng A, 431 (2006) 114-117.

[16] N. Afrin, D. L. Chen, X. Cao, M. Jahazi: Mater Sci Eng A, 472 (2008) 179-186.

[17] P. Cavaliere, P. P. De Marco: J Mater Process Technol, 184 (2007) 77-83.

[18] B. M. Darras, M. K. Khraisheh, F. K. Abu-Farha, M. A. Omar: J Mater Process Technol, 191 (2007) 77-81.

[19] R. Ch. Zeng, W. Dietzel, R. Zettler, C. H. E. N. Jun, K. U. Kainer: Trans Nonferrous Met Soc China, 18 (2008) s76-s80.

[20] A. R. Rose, K. Manisekar, V. Balasubramanian: Trans Nonferrous Met Soc China, 21 (2011) 974-984.

[21] P. Cavaliere, P. P. De Marco: Mater Charact, 58 (2007) 226-232.

[22] F. Chai, D. Zhang, Y. Li: J Magnesium Alloys, 3 (2015) 203-209.

[23] S. H. C. Park, Y. S. Sato, H. Kokawa: Metall Mater Trans A, 34 (2003) 987-994.

[24] S. H. C. Park, Y. S. Sato, H. Kokawa, J Mater Sci, 38 (2003) 4379-4383. 